\title{
DIASPORIC AND CROSS-CULTURAL IDENTITIES IN PAKISTANI FILM KHUDA KE LIYE (IN THE NAME OF GOD) Masroor Sibtain $^{1 *}$, Asad Javaid ${ }^{2}$, Talha Aslam ${ }^{3}$, Zafar Iqbal ${ }^{4}$ \\ ${ }^{1 *}$ Government Graduate College of Science, Multan, Pakistan; ${ }^{2}$ University of Central Punjab, Lahore, Pakistan; \\ ${ }^{3}$ Bahria University, Islamabad, Pakistan; ${ }^{4}$ Minhaj University Lahore, Pakistan. \\ Email: ${ }^{1 *}$ zammad.aslam@ @mail.com, ${ }^{2}$ asad.javaid@ucp.edu.pk, ${ }^{3}$ talha@ @ shor.pk, ${ }^{4}$ zafar.iqbal.publishing@gmail.com
} Article History: Received on $11^{\text {th }}$ April 2021, Revised on $16^{\text {th }}$ June 2021, Published on $25^{\text {th }}$ June 2021

\begin{abstract}
Purpose: The study aims to identify the various diasporic identities, hybrid identities, and identity crisis analyses of a Pakistani film, 'Khuda Kay Liye' released on July 20, 2007, written, directed, and produced by Shoaib Mansoor.
\end{abstract}

Method: The present study is qualitative by nature and interpretive by approach. The researchers collected the primary data from the film watching it profoundly. The secondary data was collected from the various relevant articles published in periodicals/journals to build the theoretical argument - analyzing the data utilizing the thematic analysis technique.

Main Findings: This qualitative analysis enlightens more significant issues about diaspora and identities in the focused film. Individuals in the film represent themselves distinctive living in another society, culture, or religion, practicing their native (Pakistani) cultural norms and ideologically. Moreover, as a subordinate ethnic group, specifically Muslim characters in the film, face discrimination and oppression. Through qualitative discussions based on excerpts dealing with socio-cultural behavior, the researchers concluded that diasporic identities constitute the core thematic content of the film.

Application of the Study: The study would be significant for understanding diasporic and hybrid identities. The academic researcher may adopt the theoretical framework of the present research to employ it on the other genres of Pakistani literature to find the diasporic identities and identity crises. The teachers of Pakistani literature would also seek help to understand and teach the concepts analyzed in the research.

The Study's Originality: The study is contemporary as it employs conceptual, theoretical frameworks to explore the diasporic features in a film.

Keywords: Diaspora, Diasporic Identities, Identity Crisis, Pakistani Diaspora, Hybrid Identities.

\section{INTRODUCTION}

Migration holds a pivotal place in the history of Islam as the Islamic history begins with the migration-hijra, from Makkah to Medina in 622 (Karpat, 1996; Qureshi and Lodhi, 2011; Rahman et al., 2015; Haydar, 2019). Afterwards, Muslims migrated from the first state (Medina) of Islam to all over the world. For settlement, the migration of Muslims to the Indian subcontinent started after the entrance of Muhammad Bin Qasim (Gabrieli, 1965). After the settlement in India and the Indian merchants, Muslims also migrated to various parts of Central Asia and Russia from various parts of the Indian Sub-continent, i.e., from Gujrat, Delhi, Rajasthan, Bombay, or Allahabad. The people call them 'Banias', 'Shikarpuris' or 'Multanis' (Damodaran, 2018). It was the first diasporic identity linked explicitly to the Pakistani diaspora, called historically "Indian Merchant Diaspora" (Levi, 2002). Many Muslims travelled to England and other European countries during the British rule of the Subcontinent. Pakistanis, like people from other developing countries, migrated to the United Kingdom, Europe, and America for getting good jobs (Peach, 2006), higher education (Moldenhawer, 2005), or learning advanced industrial advancement. The migrants who migrated for education or learning new knowledge remained in contact with their families back to their native lands (Adkoli, 2006), yet some stayed there marrying native individuals (Dale, 2008) or getting permanent residencies or citizenships. In this way, Pakistanis also became a permanent part of America, Great Britain, and European canvas. Thus, the Pakistani diaspora in these countries developed its roots. On a larger scale, Muslims are reported to be more than 2.2 million in Europe and 3.45 million in America (Mohamed, 2017).

The paper focuses on different themes emphasized by the Pakistani film Khuda Ke Liye scriptwriter, such as identity crisis, diaspora, cross-cultural conflict, and arbitrary positioning through hailing and interpretation. Further, across all boundaries of nationality, gender, economic, and religious this film touches the soul and focuses on interpreting different cross-cultural themes. It does so through gripping and masterful storytelling exploited by the author.

The researchers divided the present research into five main sections. The first section contains certain questions that refer to the revival/emergence of ethnic and diasporic identities of emigrants from Pakistan to Britain and the USA. The second section focuses on the theoretical framework or literature review consisting of the previous research, terms, and theories to defend the researcher's claim. Third section deals with research questions and methodology adopted for the research. The fourth section analyses the scenes which are taken from the film "Khuda Ke Liye". Finally, in conclusion, ethnic and diasporic identities are evaluated and concluded based on analyses. 


\section{Background of the film}

This film brings the situational racism and discrimination that Pakistanis, especially Muslims, faced in America after 9/11. The film also draws a line between the fundamentalists and liberal views regarding Islam which caused a cold hate war between the Westerners and Muslims (Zammad and Talha, 2018). Liberal Muslims living in western countries seemed to criticize fundamentalists in the film. Two brothers, Sarmad and Mansoor (musicians), from a liberal Muslim family, seemed living happily before Sarmed eventually changed his views from liberal to fundamentalist, are influenced by an Islamic activist Maulana Tahiri. Sarmad left his music career calling it 'haram' (forbidden in Islam). Later, Sarmad married a girl (westernized Pakistani) forcefully brought by her father from Britain to Pakistan, saving her from her nonMuslim boyfriend, Dave.

Simultaneously, Mansoor, to enhance his music career, goes to Chicago for an advanced degree in music, there he fell in love with Janie (a non-Muslim American girl) and got married to her. Eventually, 9/11 happened, and Mansoor got detained by the FBI and sent to Guantanamo Bay detention camp, where he received inhuman treatment because of his Muslim name and identity. Hence, the film revolves around the two basic practices of Islam; the fundamentalists and liberals (Zammad \& Talha, 2018) that eventually ends up with a win of liberal thoughts. Hence, the film represents the Pakistani diasporic identities, especially in America and Britain.

\section{THEORETICAL FRAMEWORK}

Culture deals with the social construction and accepted norms embedded in different social behavior patterns (Goode, 1994; Timol, 2020). The concept of binary oppositions, which still exist in society, results from the division between the two (powerful/powerless, master/servant) and different socio-racial backgrounds that people belong (Batkalova, 2018). Cultural backgrounds and variations create different ideologies deeply rooted in people's minds and reflected from their behaviours (Lugrin, 2018; Baig et al., 2019). These ideologies are reflected in traditions, norms, brought ups, and even in dressing styles (Tanatova et al., 2020). Culture is a way of being in life, and it always focuses on the set of practices and actions (Bilá, \& Ivanova, 2020) by its followers. Culture is created by the social interaction of its individuals and accepted in different social contexts focusing on different social practices by its inhabitants, and these social practices lead to the social identity of those individuals living in that society.

\section{Cross-Culturalism and Multi-Culturalism}

This idea of "Pluralism" originates and then advances in the colonization era when colonies developed by the colonizers and later transformed into multi-culturalism (Adebanwi, 2018). It deals with the idea of rule through power and dominates the poor or is suppressed by intimidating power (Ayson, 2018). With their excessive use of power, the colonizers captured the suppressed and ruled over them by their desire and will (Müller-Crepon, 2020). Various researchers argue that 'power corrupts, and absolute power corrupts absolutely, and the colonizers were the strong followers of this saying (Cislak, 2018). Furnivall (1939; 1948), The societies of the Dutch East Indies were studied by a Dutch administrator. "When a country, formerly governed by colonists, possesses the following broad political, cultural, and economic features, it is referred to as a multi-cultural society.

a) It, culturally, consists of the groups which are diverse and do not share the same religion, norms, and traditions. Moreover, they have different ways of life as well.

b) Economically, the people of these different groups have their different social identities, and they only interact in markets, especially during buying, selling, and in case of any trade purposes.

c) Politically, these disparate but economically interacting segments are held together by a superordinate authority-that is the colonial rulers (Furnivall, 1948 cited in Gautam, 2013). In other words, these socially disillusioned but economically merged groups of people are brought together by one superordinate and powerful authority, that is, the colonizer (colonial rulers). In the dual community, a poly-ethnic community is incorporated with various social groups in the industry under the control and control of a management power but allowed to observe the social variety.

The people make contact at various places, and these places also give independence to individuals to communicate (Horta and Yonezawa, 2013). For instance, trade centers, industries, properties for farming, locations of joyful or spiritual meetings, taxes centers, police force centers, or playgrounds in cities or suburbs contribute their roles in these type of contact/connections (Gluckman, 1940 cited in Tholoniat and de L'Estoile, 2008). Therefore, the interrelationship and lifestyle's associations with the social individuals make this idea critically compelling. In any dual cultural or social setup, subordination often gets discriminated against (Martin, 2020) in every competition in swapping ideas and services. Hence, subordinate cultures maintain their identity, avoiding significant cultural influences (Ralston et al., 2009). For instance, they maintain their 'core values' through their distinctive social identity literary works (Coley, 2020). Henceforth, in the present case, as in the case of Pakistani identity in America, the writer of the film highlight/represents various social identities in the context of the Pakistani Diaspora (see Section 4.1 for more details). 


\section{Ethnicity}

The process of ethnicity involves migration (Segal, 2019), claiming citizenship rights from a state, and mixing with the indigenous culture (Nielsen and Leighton, 2017). The underprivileged person experiences a new encounter in the process (Frydenlund, 2019). Cultural background, in the process, removes their native identity to a particular extent (Aschhoff and Vogel, 2019). In American settings, the same was experienced by the Pakistani community when dealt with as a minority (Akhtar et al., 2020). The media and state laws opposed the Pakistani lifestyle. "Ancestors' connections, kinship interaction, and memories" control the immigrants" identity; therefore, it is imperative to defend and sustain the traditional ethnicity and identity. Holmes and Wilson (2017) argue that people often speak in the same way living together. However, when various ethnicities live together, they often share some universal linguistic feature, yet they speak fictively to maintain their separate social identity in various situations. They adapt these fictive features from their native cultural lexicon making it specific jargon. These linguistic features distinguish them from the significant social network settings to maintain ethnicity. It is the way; they construct or reconstruct their social identities.

Ethnicity can further be explained as “the definition or ascription of a group's identity may be the subject and outcome of a cross-boundary struggle for control; that the social identity of a group may also be contested within the group itself, on grounds related to the cross-boundary interaction; that discourse about identity within the boundary tends to focus on its absolute character" (Cohen, 2000, p. 5). The study of ethnicity "has helped us understand the signaling effects of cultural idioms whereby membership in contested, ethnic symbols are made visible and thereby socially effective" (Barth, 2000, p. 34). The term "ethnic" has often been used by anthropologists and ethnologists alike. The term as such was used for a self-perpetuating biological group, sharing cultural values, communication, and distinctness from other groups (Gautam, 2013, p. 8).

\section{Diaspora}

The term "Diaspora" originates from an ancient term dispersion (Grossman, 2019). Since dispersion refers to movement, one place to another due to some reasons (Lewis et al., 2013), diaspora can also be used in the same context (Ogunyemi, 2020). In post-colonial literature, this term is significantly essential as it focuses on the concept of displacement, and in history, many groups had to displace for different reasons (McLeod, 2020). It was used by the Jews, denoting their worldwide dispersion outside their country, the Area of Israel. In Hebrew, it means 'Golah' or 'Galut', significance "Exile" (Gelbin, 2017). Since the Jews rejected incorporating and getting encountered with repression, they shifted out of Israel (Comay, 1981; Silverburg, 2020). Although they lived with different social groups because of this dispersion, Jewish people still followed their traditions and social norms, keeping their social identity alive. Migration also prolonged the limitations of the Judaism Diaspora. The design of Judaism Diaspora has been followed by the Armenian, China, Africa (slavery), and Indian/Pakistani areas.

\section{RESEARCH METHOD}

The researchers adopt the qualitative approach for data analysis. The themes such as ethnicity, diaspora, identity crisis, and arbitrary cultural clashes emerge from the researcher's observations after watching the film. The primary source is a Pakistani film gathering information watching-film critically. Published research papers, articles in journals are the secondary source.

\section{Questions}

For discussions and analysis regarding the Pakistani Diaspora in European \& American culture, the paper looks at the following questions:

- What has been the process of diaspora and settlement of Pakistanis in Western countries?

- How did they unite as a Pakistani group and give up their heterogeneous multi-regional, linguistic, religious, and cultural identities?

- How did they develop self-maintained organized associations and maintain their Pakistani identity?

- How has the language been used to reflect the themes of Positioning (Hailing and Interpellation), Identity crisis, and Politics at the level of religion and naming in the film?

\section{FINDINGS AND DISCUSSION}

\section{Identity (ies) differentiations in the diaspora}

In the western setting, the character, 'Sheikh' represents the fundamentalist ideology of religion as he said to 'Hussain' (Mariyam's father):

Kiun Deen Ko Kharab Kr Rahay Ho, Naam Nawasa-e-Rasool Ka Aur Kaam Abu Jehal K (Scene, 06:52- 07:30) (trans. Why are you putting a bad name to religion, your name belongs to Grandchild of Holy Prophet (Hussain), but your deeds are of Abu Jehal (Enemy of Islam)? 
In the above example, the use of language by the rigid fundamentalist is harsh and unappealing, i.e., if one wants to be a good religious person, one should have to follow the real follower of the religion, but the character 'Hussain' does not follow the Hussain R.A. (the grandson of the Prophet of Islam) according to the fundamentalist. Although the characters (Sheikh and Hussain) live in London, they have their own personal cultural, religious, and ethnic identities, which would never be changed due to diasporic movements. Living among the 'others, they are trying to maintain their own 'self', but they also prefer their foreign diasporic identity as the fundamentalist character (Sheikh) has been threatened by Hussain. i.e.

Jatay Ho Tum Yahan Se, Ya Police Ko Bolaon? (trans. Leave! Otherwise, I will call the police).

In the Western setting (London), the Muslim (Hussain) tries to prefer his adopted diasporic identity or religious identity when he decides to call the police and ignores the real message given by another Muslim (Seikh), he tries to propagate the real understanding of religion to a deviant Muslim (Hussain).

\section{Hybrid Identity (ies) \& Identity Crises}

Identity may become hybridised due to diasporic movements and cross-cultural sharing or marriages, leading to identity crises. i.e., British national Mary's (actually Maryum) Pakistani father who has disapproved of her daughter's marrying her white boyfriend having a different identity, although he (father) himself lives there with a white woman (having a different identity). Her father brings her to an isolated village in Pakistan and gets her married, without her consent to completely transformed Sarmad (living in Pakistan), having approximately the same identity as Maryum and Hussain. However, she was brought up in a Western (London) atmosphere, so she has differences with Sarmad both culturally and socially, representing the liberal kind while the other is a deviant liberal individual.

Syed kay ghar Miraspan ghus aya tha kitny din chalta, (Scene, 23:45-24:05) (trans. Singing has emerged into the family of Syed, for how long it will continue?)

The use of language in the above scene has reflected the concept of an identity crisis. The old lady (Dadi), being a traditional lady, criticizes the art of singing and is proud of her ancient identity as being a member of Syed's family. Here, it is shown through the words that tradition invariably clashes with change. Dadi (tradition) is against the concept of singing (a tool of change in tradition). Identity keeps on changing, and it has been shown in the film that the liberal identity is introduced through a broad-minded singer (Sarmad). However, later he is shown undergoing a transformation and changing into a rigid and fanatic minded fundamentalist by a rigid maulvi, so his identity has changed, and then, in the end, he returns to his original identity (of the singer).

A dramatic clash of hybridist culture between two rock musicians is unfolded through the film, the impressionable Sarmad and the liberal Mansoor completely messed up and brainwashed by the maulvi. Ironically, turmoil has engulfed both brothers, scarring their happy-family idyll for the rest of their lives. On the other hand, Mansoor is imprisoned in the notorious US prison and tortured for his claimed ties to Al-Qaida (a so-called terrorist group). However, Sarmad becomes a hostage in a cruel game in which a bereft father uses him to forcibly prevent his British-born daughter from marrying her lover in UK (a British boy). Further, the young boy was compelled to work as a mujahid in war-torn Afghanistan, despite his hatred of violence and declaration that he could not murder a man. To illustrate the corrosive fallout of a view about religion, the film was shot in three countries: America, England, and Pakistan. If the people of America are guilty of associating Islam with terrorism, a segment of the Muslim community is also responsible for holding the world and their community hostage with their distorted views.

The film introduces us to the liberal and music-loving family, whose two boys are artists, and it further deals with numerous topics such as diaspora, arbitrary placement, ethnicity, racism, and identity crisis (interpellation and Hailing). The character of Sarmad is impressionable, but Mansoor, the older brother, is known to what he wants. Sarmad's innocuous trips to a Maulana who tries to transform him into an eviller are significant. The mysterious maulvi, a hardline fundamentalist, is converting the naive child into a fundamentalist. Although the jeans and music faded away, the beard grew, and he demanded that his mother wear a headscarf, which she rejected. Sarmad commits more brutal acts when under the influence of Maulana. It seems that he has no idea he is capable of it.

Meanwhile, Mansoor went to America to pursue music and fall in love with a white fellow student. Although further, everything seemed good for some time, he pulled up for interrogation based on his Muslim name. Mary has refused to give up after two years of misery and writes a letter to her boyfriend that starts everything. Sarmad's father has arrived to get her and whisk her away to safety. She refused to return to the UK after arriving in Pakistan and instead opted to sue her father and Sarmad in court of law.

\section{Clash of Ideologies}

Furthermore, the language utilized in the film depicts a conflict of ideologies between two schools of Islam, and these schools claimed to be preaching the actual Islamic beliefs. On the one hand, there is the fundamentalist interpretation, as embodied by Tahirih's beliefs. While his sermons are based on jihad and an understanding of Islam as a conventional faith that rejects women's rights and deems music and art as haram (forbidden), the preacher brainwashes the young Pakistanis. On the other side, there is the liberal face of the film, which is represented by two key characters. Mansoor, a 
young singer who refuses to follow dogma and, as a result, becomes a victim of racial profiling and human rights violations in the United States. Maulana Wali is a religious scholar who has beaten extremists at their own game. The Maulana in question has demonstrated that Islam is not anti-woman or against music, art, or culture by quoting extensively from holy sources. However, it has also promoted the idea of jihad, misunderstood by extremist maulvi Tahirih as a struggle to overcome the faults inside the flawed human.

"Din mein daadi hai, daadi mein din nahin" (Scene, 2:26:34-2:26:45 (trans. The beard lies in religion; religion does not lie in the beard)

Libas ka taaluq mashrat se h, mazhib se bilkul nahi, (Scene 2:25:35-2:25:45) (trans. Dress belongs to culture and society instead of religion).

The lines mentioned above show the liberal and broad-minded concept of religion. The religious scholar Maulana Wali (Naseer-Din Shah) has given the cogent interpretation of the religion by quoting different authentic references. Here, Maulana Wali addresses all the Muslims (addressees) to understand Islam's true sense and spirit, so the researchers also analyse themes of interpellation and hailing. It also shows that dress belongs to the society, religion has a far broader concept, and it (religion) always facilitates the Muslims instead of giving them pain.

"I do not belong to a poor family, but you do belong to a poor country" (Scene, 1:35:26-1:35:35)

These words reflect the western perception (orientalism) of Pakistan. It shows that the West (America) thinks that Pakistan has no identity and is a very poor or powerless country. "You do belong to a poor country" this clause clearly explains their hidden motive and hatred for Muslims, especially Pakistanis. The Americans think that the survival of Pakistan is only dependent on their financial aid, and this is the politics that America has been playing with the Pakistanis, especially after 9/11.

Not all Muslims are terrorists, but all terrorists are Muslims because Muslims are the only nation subjected to the nation. (Scene, 1:56:55-1:57:05)

Whenever there is any incident of terrorism, somehow it will always relate to the 'Muslims (Politics in the name of religion). Innocent Muslims get jailed because of their religious association by the western forces with impunity. Muslims have been killed and considered terrorists only because of their religion. It has been shown in the film that Americans badly misinterpret the true meaning of Islam, and Mansoor (Shan) has been charged and interrogated only because of his religion (Islam). However, he (Mansoor) tries to prove his innocence by telling the truth and referencing different things, but the officer (representative of West) has forced him (Mansoor) to speak about Osama Bin Laden, and in the end, declared Mansoor, a terrorist. America, being super-ordinate, has tried to suppress the Muslims (subordinate). There is also the concept of binary oppositions as America (Powerful) and Pakistan (Powerless), the ruler and the ruled. The West (America) cannot accept the Muslims at any cost, especially in their culture, and threaten them.

\section{CONCLUSION}

The research concludes that the film has shown three different people from different continents having problems that relate to South Asian culture and the subsequent misinterpretations of Islam in Pakistan's and Western society. The film 'Khuda Kay Liye' is just a gripping tale; it also features excellent acting, a memorable piece of music, and superb production elements. The protagonist barely appears in the film's last seconds but packs enough punch to create a lasting impact, is unsurprisingly the scene-stealer. His opponent, hardline mullah Taheri, is a match for him, with actor Rasheed Naz pouring fire and brimstone within the mosque's boundaries with speeches that are a lethal blend of politics and religion. Here comes the role of third cinema in the limelight as it always focuses on the grey areas, and in this film, it may seem interpreted that those grey areas are vivid, especially among Muslims and Western people. It is original, bold, and courageous and tackles the relationship between moderate Muslims and extremists. Meanwhile, the film's production value might be higher, and the story of the film can be less melodramatic if it didn't have so many stereotyped characters. Despite these faults, the film is gripping. There is also a solid and clear message in the film that-Islam is not about terrorism; it is a religion of peace, and it is also against forced marriages.

\section{LIMITATIONS AND SUGGESTIONS FOR FUTURE RESEARCH}

The researchers analyzed the data focusing on the themes mentioned in the research, i.e., diasporic identities and identity crisis related to Muslim Pakistani ethnic groups living in Chicago and London (as represented in the film). Muslim diaspora and identity crises may appear distinctive in other western counties or locations. Moreover, the film may represent other social issues that the researchers might not explore. The future researchers would explore the social issues, i.e., oppression towards women, fundamentalism. Moreover, future researchers may adapt and modify the conceptual framework for further improvements.

\section{ACKNOWLEDGEMENT}

The present research does not utilize any financial support from any organization. 


\section{AUTHORS CONTRIBUTION}

Masroor Sibtain: Devised the research design. Started the paper and finished till end working on each part, proofread and edit the paper.

Asad Javaid: Worked the theoretical framework and methods.

Talha Aslam: Devised the idea and theoretical framework.

Zafar Iqbal: Worked on data collection and raw interpretations.

\section{REFERENCES}

1. Adebanwi, W. (2018). Contesting multiculturalism: ethno-regionalism and contending forms of nationalism in late colonial Nigeria. Commonwealth \& Comparative Politics, 56(1), 40-64. https://doi.org/10.1080/14662 043.2017 .1312731

2. Adkoli, B. V. (2006). Migration of Health Workers: Perspectives from Bangladesh, India, Nepal, Pakistan and Sri Lanka. In Regional Health Forum (Vol. 10, No. 1, pp. 49-58). World Health Organization, Regional Office for South-East Asia.

3. Agnihotri, R.K. (1987). Crisis of identity: The Sikhs in England. New Delhi: Bahri Publications.

4. Aschhoff, N., \& Vogel, R. (2019). Something old, something new, something borrowed: Explaining varieties of professionalism in citizen collaboration through identity theory. Public Administration, 97(3), 703-720. https://doi.org/10.1111/padm.12589

5. Akhtar, S., Baig, F. Z., Aslam, M. Z., Khan, T., Tayyaba, S., \& Iqbal, Z. (2020). Code-Switching and Identity: A Sociolinguistic Study of Hanif's Novel Our Lady of Alice Bhatti. International Journal of English Linguistics, 10(1), 364-371. https://doi.org/10.5539/ijel.v10n1p364

6. Ayson, R. (2018). The coercive power of shared values. Political Science, 70(3), 189-206. https://doi.org/10.1080/00323187.2019.1595065

7. Baig, F. Z., Yousaf, W., Aazam, F., Shamshad, S., Fida, I \& Aslam, M. Z. (2019). Power, Ideology and Identity in Digital Literacy: A Sociolinguistic Study. International Journal of English Linguistics, 9(2), 252-264. https://doi.org/10.5539/ijel.v9n4p252

8. Barth, F. (1969). Ethnic Groups \& Boundaries. Oslo: Jhansen \& Nielsen.

9. Barth, F. (2000). "Boundaries \& Connections" In Anthony Cohen (ed.) Signifying Identities: Anthropological perspectives on boundaries and contested values. London and New York: Routledge.

10. Batkalova, K. (2018). Binary oppositions in traditional culture of japanese and kazakh people. Astra Salvensis, 6(11), 463-480.

11. Bilá, M., \& Ivanova, S. V. (2020). Language, culture and ideology in discursive practices. Russian Journal of Linguistics, 24(2), 219-252. https://doi.org/10.22363/2687-0088-2020-24-2-219-252

12. Cislak, A., Cichocka, A., Wojcik, A. D., \& Frankowska, N. (2018). Power corrupts, but control does not: What stands behind the effects of holding high positions. Personality and Social Psychology Bulletin, 44(6), 944-957. https://doi.org/10.1177/0146167218757456

13. Cohen, A. P. (Ed.). (2000). Signifying identities: Anthropological perspectives on boundaries and contested values. Psychology Press.

14. Coley, D. K. (2020). Literary Value and Social Identity in the" Canterbury Tales." by Robert J. MeyerLee. Studies in the Age of Chaucer, 42(1), 425-429. https://doi.org/10.1353/sac.2020.0027

15. Comay, J. (1981). The Diaspora Story: The epic of the Jewish people among the nations. Weidenfeld and Nicolson.

16. Dale, A. (2008). Migration, marriage and employment amongst Indian, Pakistani and Bangladeshi residents in the UK. University of Manchester, CCSR Working Paper, 2, 1-10.

17. Damodaran, H. (2018). India's new capitalists: caste, business, and industry in a modern nation. Hachette India

18. Frydenlund, S. A. (2019). Situationally Sherpa: race, ethnicity, and the labour geography of the Everest industry. Journal of Cultural Geography, 36(1), 1-22. https://doi.org/10.1080/08873631.2018.1516601

19. Furnivall, J. S. (1939). Netherlands India: A study of plural economy. Cambridge: Cambridge University Press

20. Furnivall, J. S. (1948). Colonial policy and practice. New York: New York University Press.

21. Gabrieli, F. (1965). Muhammad ibn Qāsim ath-Thaqafi and the Arab Conquest of Sind. East and West, 15(3/4), 281295. Retrieved June 9, 2021, from http://www.jstor.org/stable/29754928

22. Gautam, M. K. (2013). Indian diaspora: ethnicity and diasporic identity. Migration Policy Centre, CARIMIndia Research Report, 2013/29 Retrieved from Cadmus, European University Institute Research Repository, at: http://hdl.handle.net/1814/29491

23. Gelbin, C., \& Gilman, S. (2017). Cosmopolitanisms and the Jews (p. 353). University of Michigan Press. https://doi.org/10.3998/mpub.8174299

24. Gluckman, M. (1940). Analysis of a social situation in modern Zululand. Bantu studies, 14(1), 1-30. https://doi.org/10.1080/02561751.1940.9676107

25. Goode, E., \& Ben-Yehuda, N. (1994). Moral panics: Culture, politics, and social construction. Annual review of sociology, 20(1), 149-171. https://doi.org/10.1146/annurev.so.20.080194.001053 
26. Grossman, J. (2019). Toward a definition of diaspora. Ethnic and Racial Studies, 42(8), 1263-1282. https://doi.org/10.1080/01419870.2018.1550261

27. Hall (1993). "Encoding/Decoding." S. During (ed.), The Cultural Studies Reader. London and NY: Routledge.

28. Haydar, A. (2019). The Mohajirs in Sindh: A Critical Essay. In Contemporary problems of Pakistan (pp. 107124). Routledge. https://doi.org/10.4324/9780429041723-6

29. Holmes, J., \& Wilson, N. (2017). An introduction to sociolinguistics. Routledge. https://doi.org/10.4324/9 781315728438

30. Horta, H., \& Yonezawa, A. (2013). Going places: exploring the impact of intra-sectoral mobility on research productivity and communication behaviors in Japanese academia. Asia Pacific Education Review, 14(4), 537547. https://doi.org/10.1007/s12564-013-9279-4

31. Karpat, K. (1996). Muslim Migration: A Response to Aldeeb Abu-Sahlieh. International Migration Review, 30(1), 79-89. https://doi.org/10.1177/019791839603000108

32. Khan, A. W. (2006). Life of Prophet Muhammad. LIFE, 1, 2

33. Levi, S. C. (2002). The Indian Diaspora in central Asia and its trade, 1550-1900. Brill.

34. Lewis, M. A., Maini, P. K., \& Petrovskii, S. V. (2013). Dispersal, individual movement and spatial ecology. Lecture Notes in Mathematics (Mathematics Bioscience Series), 2071. https://doi.org/10.1007/978-3642-35497-7

35. Lugrin, B., Frommel, J., \& André, E. (2018). Combining a data-driven and a theory-based approach to generate culture-dependent behaviours for virtual characters. In Advances in Culturally-Aware Intelligent Systems and in Cross-Cultural Psychological Studies (pp. 111-142). Springer, Cham. https://doi.org/10.1007/978-3-31967024-9_6

36. Martin, J. (2020). Multiculturalism and feminism. In Intersexions (pp. 110-131). Routledge. https://doi.org/10.4324/9781003116165-7

37. McLeod, J. (2020). Diaspora identities. In Beginning postcolonialism (second edition). Manchester University Press. https://doi.org/10.7765/9781526153531.00013

38. Mohamed, B. (2018). New estimates show U.S. Muslim population continues to grow. Retrieved from https://www.pewresearch.org/fact-tank/2018/01/03/new-estimates-show-u-s-muslim-population-continues-togrow/ on June 10, 2021

39. Moldenhawer, B. (2005). Transnational migrant communities and education strategies among Pakistani youngsters in Denmark. Journal of Ethnic and Migration Studies, 31(1), 51-78. https://doi.org/10.1080/136 9183042000305681

40. Müller-Crepon, C. (2020). Continuity or change? (In) direct rule in British and French colonial Africa. International Organization, 74(4), 707-741. https://doi.org/10.1017/S0020818320000211

41. Nielsen, L., \& Leighton, R. (2017). What are the gender, class and ethnicity of citizenship?: A study of upper secondary school students' views on Citizenship Education in England and Sweden. Confero: Essays on Education, Philosophy and Politics, 5(1), 11-70. https://doi.org/10.3384/confer.2001-4562.170530

42. Ogunyemi, O. (2020). On the issue of diaspora's terminological dispersal. Journal of Global Diaspora \& Media, 1(1), 3-14. https://doi.org/10.1386/gdm_00001_2

43. Peach, C. (2006). South Asian migration and settlement in Great Britain, 1951-2001. Contemporary South Asia, 15(2), 133-146. https://doi.org/10.1080/09584930600955234

44. Qureshi, S. A., \& Lodhi, M. I. (2011). Holy Prophet (PBUH) as a Preceptor for All Times. Dialogue (Pakistan), 6(4), 300-318.

45. Rahman, F. N., Sami, K., \& Memon, M. F. (2015). Medina charter and just peacemaking theory. The Government-Annual Research Journal of Political Science., 4(4), 196-203.

46. Ralston, D. A., Egri, C. P., Casado, T., Fu, P., \& Wangenheim, F. (2009). The impact of life stage and societal culture on subordinate influence ethics: A study of Brazil, China, Germany, and the US. Journal of International Management, 15(4), 374-386. https://doi.org/10.1016/j.intman.2009.02.004

47. Segal, U. A. (2019). Globalization, migration, and ethnicity. Public Health, 172, $135-142$. https://doi.org/10.1016/j.puhe.2019.04.011

48. Silverburg, S. R. (2020). An International Legal Bibliography on the Palestinian-Israeli Conflict. Denver Journal of International Law \& Policy, 10(2), 7.

49. Tanatova, D. K., Yudina, T. N., Fomicheva, T. V., Dolgorukova, I. V., \& Sulyagina, J. O. (2020). European traditions in culture of russians. Laplage em Revista, 6(Extra-C), 100-113. https://doi.org/10.24115/S2446622020206Extra-C633p.100-113

50. Tholoniat, Y., \& de L'Estoile, B. (2008). Max Gluckman (1940): «Analysis of a social situation in modern Zululand». Genèses, (3), 119-155. https://doi.org/10.3917/gen.072.0119

51. Timol, R. (2020). Ethno-religious socialisation, national culture and the social construction of British Muslim identity. Contemporary Islam, 14(3), 331-360. https://doi.org/10.1007/s11562-020-00454-y

52. Zammad, A. M., Talha, A. (2018). Ideological Positioning of the Islamic Fundamentalists and Moderates in Khuda Kay Liye (In the Name of God: A Pakistani Movie). Arts Social Sci. J., 9, 376. ttps://doi.org/10.4172 $\underline{12151-6200.1000381}$ 